\title{
Da circulação de biscoitos à verdade na ciência
}

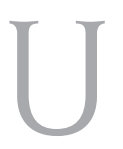

ma chamada publicitária que fez história ensinava que determinados biscoitos vendiam mais porque eram bem fresquinhos e eram bem fresquinhos porque vendiam mais. A busca pela indexação de nossa Revista Brasileira de Reumatologia passa também por essa lógica. Se mais e mais trabalhos científicos, e principalmente artigos originais, tiverem como escolha a publicação em nossa revista, ela deverá atingir o nível de exigência para a indexação e passará a ser cobiçada pelos autores para publicação. Não é de hoje a proposição de que deveria se tentar um esforço coletivo, estimulando que trabalhos de "peso" priorizassem a RBR. Mas outros interesses acadêmicos e curriculares são naturalmente mais atraentes e fecha-se o círculo na contramão da parábola dos biscoitos.

Entre possíveis alternativas estratégicas, tornar a revista bilíngüe, com a versão para o inglês não só dos abstracts, mas da totalidade dos textos poderia tornar nossa produção científica mais conhecida.

O estímulo a temas "nacionais", enfermidades que são mais prevalentes em nosso meio, também é uma maneira de aguçar o interesse da comunidade científica internacional. A globalização ensina que o peculiar faz a diferença. A propósito vale a lembrança das palavras do médico mexicano Ignácio Chávez (1897-1980): "Necessitamos criar nós mesmos, fazer ciência nós mesmos e não passar a vida rezando as verdades e os erros que nos legam os outros. Enquanto não fizermos isso, seremos os eternos ignorados no mundo científico e os eternos incapazes para resolver nossos problemas de acordo com a própria realidade".

A produção científica de nossa reumatologia, bem demonstrada em nossos eventos, há muito apresenta inquestionável valor; precisamos, no entanto, identificá-la mais como nossa, eis um dos papéis da revista. Premiar de alguma forma os autores, estimulando-os, é outra proposta a ser estudada em uma discussão de mudanças previstas para o Fundo de Auxílio à Pesquisa e Ensino em Reumatologia da SBR.

A RBR é um dos nossos maiores patrimônios e veículo para uma das grandes motivações da existência da Sociedade Brasileira de Reumatologia. Além da congregação de associados unidos por uma mesma especialidade, o balizamento de boas condutas éticas, a promoção da educação continuada visando a uma assistência médica digna à população que sofre devido às doenças reumáticas, estimular e divulgar ciência é obrigatório. Mantendo sempre sensibilidade e razão, na ciência, a verdade. Valho-me do imortal escritor espanhol Miguel de Cervantes Saavedra (1547-1616): "Nenhuma ciência, enquanto ciência, engana; o engano está em quem não a conhece".

Ao finalizarmos a gestão, acalenta-nos a certeza de que aqueles que nos sucedem alcançarão conquistas importantes nesse sentido e, ao agradecemos aos amigos editores Francisco Airton Castro da Rocha e Ricardo Machado Xavier, aos co-editores, revisores, autores e colaboradores da RBR nestes dois anos, com uma menção especial ao secretário editorial da revista, o dedicado Rogério Quintiliano Amaral, colocamo-nos à disposição da presidente Iêda Laurindo e de sua equipe para ajudar em tudo o que for preciso.

Também aproveitamos para agradecer a toda nossa diretoria, à nossa secretaria executiva e a todos os associados pela constante atenção e apoio. A dedicação, seriedade e prazer no trabalho será o nosso legado.

Fernando Neubarth

Presidente da Sociedade Brasileira de Reumatologia 